\title{
Increased blood pressure and erythrocyte sodium/lithium countertransport activity are not inherited in diabetic nephropathy
}

\author{
J.S. Jensen ${ }^{1,3}$, E. R. Mathiesen ${ }^{2}$, K. Nørgaard ${ }^{1}$, E. Hommel ${ }^{2}$, K. Borch-Johnsen ${ }^{1}$, J. Funder ${ }^{3}$, J. Brahm $^{3}$, \\ H.-H.Parving ${ }^{2}$ and T. Deckert ${ }^{1}$ \\ ${ }^{1}$ Steno Memorial Hospital, Gentofte, ${ }^{2}$ Hvidøre Hospital, Klampenborg, \\ ${ }^{3}$ Department of General Physiology and Biophysics, The Panum Institute, University of Copenhagen, Denmark
}

\begin{abstract}
Summary. Genetic predisposition to essential hypertension, represented by maximal erythrocyte sodium/lithium countertransport activity, has been suggested as a marker for the risk of developing clinical nephropathy in Type 1 (insulin-dependent) diabetes mellitus. To evaluate this hypothesis we measured arterial blood pressure and maximal sodium/lithium countertransport activity of erythrocytes in 80 parents of 49 Type 1 diabetic patients with clinical nephropathy, 78 parents of 49 normoalbuminuric patients and 17 age-matched non-diabetic individuals. The two diabetic groups were carefully matched. In the two groups of parents blood pressure and cell sodium/lithium countertransport activity showed no significant differences (137/83 vs $133 / 81 \mathrm{~mm} \mathrm{Hg}$ and $0.33 \mathrm{vs} 0.32 \mathrm{mmol} /(1 \mathrm{cells} \times \mathrm{h})$ respectively). The proportion of parents who had died or received antihypertensive drugs was similar in the two groups.
\end{abstract}

The patients with Type 1 diabetes had significantly higher sodium/lithium countertransport compared to the 39 non-diabetic control subjects independently of the presence or absence of nephropathy $(p<0.002)$. However, patients with nephropathy tended to have higher sodium/lithium countertransport activity than normoalbuminuric patients $(0.48$ vs $0.41 \mathrm{mmol} /(1$ cells $\times \mathrm{h}), p=0.06)$. We conclude that genetic predispositions to essential hypertension and increased maximal erythrocyte sodium/lithium countertransport activity do not appear to be risk markers for the development of clinical nephropathy in Type 1 diabetic patients.

Key words: Type 1 (insulin-dependent) diabetes mellitus, diabetic nephropathy, blood pressure, genetic predisposition, sodium/lithium countertransport.
Development of clinical nephropathy in patients with Type 1 (insulin-dependent) diabetes mellitus is associated with a very poor prognosis [1], and develops in $30-40 \%$ of the patients [2]. The key event of clinical nephropathy is proteinuria which develops in association with increasing blood pressure $[3,4]$. It is still unknown why only $30-40 \%$ of Type 1 diabetic patients develop nephropathy but it is assumed that genetic factors are involved in the pathogenesis of diabetic nephropathy.

Recently Krolewski et al. [5] and Mangili et al. [6] demonstrated elevated maximal erythrocyte sodium/lithium countertransport activity $\left(\mathrm{Na}^{+} / \mathrm{Li}^{+}\right.$countertransport) in Type 1 diabetic patients with nephropathy as compared with normoalbuminuric Type 1 diabetic patients. Furthermore Krolewski et al. [5] found a higher prevalence of hypertension in parents of patients with nephropathy than in parents of patients without nephropathy in accordance with the observations by Viberti et al. [7]. Increased $\mathrm{Na}^{+} / \mathrm{Li}^{+}$countertransport has been suggested as a genetic marker for essential hypertension in non-diabetic individuals [8-10]. Thus, these observations led the above-mentioned authors to advocate the concept that the risk of developing clinical nephropathy in Type 1 diabetes mellitus is associated with a genetically determined predisposition to essential hypertension $[5,6]$.

According to this hypothesis one would expect parents of diabetic patients with nephropathy to have a higher blood pressure and $\mathrm{Na}^{+} / \mathrm{Li}^{+}$countertransport compared with parents of normoalbuminuric patients.

Hence, the aim of the present study was to measure blood pressure and $\mathrm{Na}^{+} / \mathrm{Li}^{+}$countertransport in Type 1 diabetic patients with or without clinical nephropathy and in their parents.

\section{Subjects and methods}

All Type 1 diabetic patients under the age of 31 years with clinical diabetic nephropathy attending one of the specialized diabetes clinics in Copenhagen (Steno Memorial Hospital and Hvidøre Hospital) were identified. Clinical diabetic nephropathy was defined as persistent proteinuria (urinary albumin excretion $>300 \mathrm{mg} / 24 \mathrm{~h}$ in at 
Nephropathy group Normoalbuminuria group

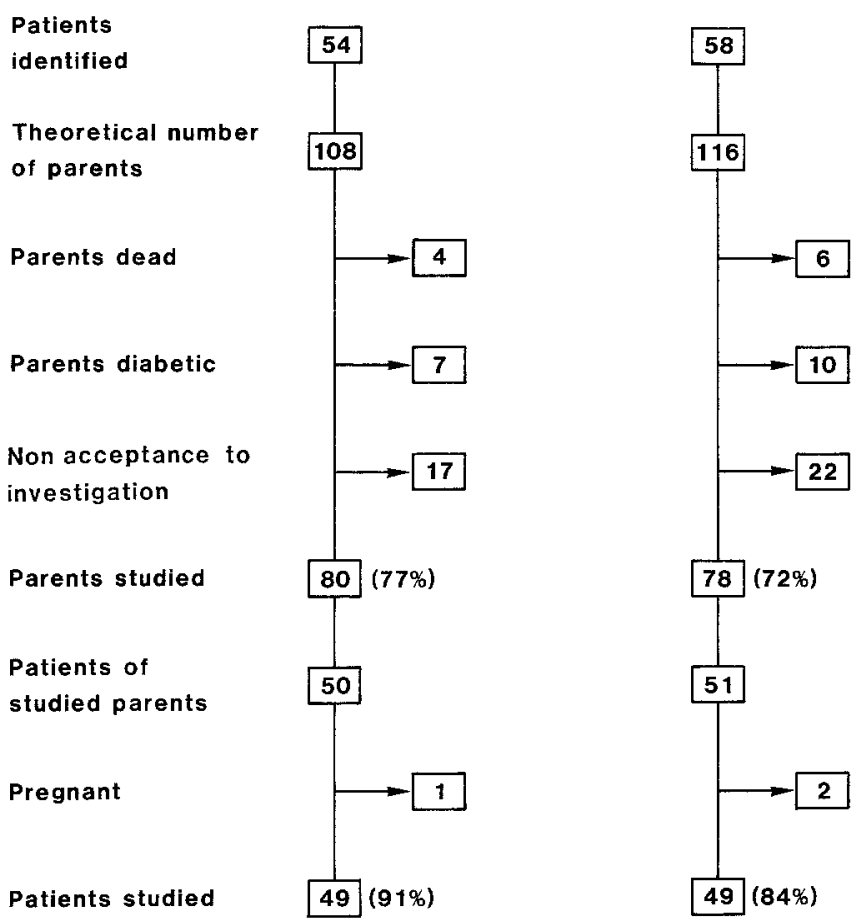

Fig. 1. Flow chart for patients and parents included in the study

least two out of three consecutive, sterile, non-ketotic $24 \mathrm{~h}$ urine samples with at least a one month interval) without clinical or laboratory evidence of kidney or renal tract diseases other than diabetic glomerulosclerosis. At the time of the study the urinary albumin excretion was below $300 \mathrm{mg} / 24 \mathrm{~h}$ in some patients due to antihypertensive treatment [11] but all patients fulfilled the criteria before antihypertensive treatment was initiated. A group of normoalbuminuric diabetic patients aged $18-31$ years with a diabetes duration of at least ten years and urinary albumin excretion below $20 \mathrm{mg} / 24 \mathrm{~h}$ was consecutively selected from all the patients attending the two clinics. All the patients with at least one parent living in a geographically well-defined area (Greater Copenhagen and surroundings) were included. All the patients had been treated from time of diagnosis with at least two daily injections of highly purified porcine or human insulin. None received medical treatment except insulin and possibly antihypertensive drugs. Fifty-four patients with clinical nephropathy and 58 patients with normoalbuminuria (an equal number from each clinic) fulfilled the criteria.

Of the potential 224 parents 10 had died and 17 parents with diabetes were excluded from the study, leaving 197 eligible parents (Fig.1). Thirty-nine parents were not studied for one of the following reasons: those who did not want to participate, they were living outside the geographical area or the patients did not give their consent to contact the parents. However, these 39 parents did not differ from the investigated parents with respect to sex, age or antihypertensive treatment. The remaining 158 parents represented 101 families and 101 diabetic patients. Three diabetic patients were excluded due to pregnancy, resulting in 49 diabetic patients in each group.

Two control groups of healthy subjects, age and sex matched with the patients and parents respectively were also studied (Table 1). All the subjects were Caucasian. All subjects gave their informed consent, and the parents were contacted only after written consent from the patient. The experimental design was approved by the local Ethical Committee.

All subjects were examined between 16.00 and 18.30 hours in the out-patients' clinics. Actual medication, history of hypertension, renal disease and cardiac disease were recorded for each subject.

Systolic and diastolic blood pressure were measured twice and averaged with patients in the supine position after $10 \mathrm{~min}$ rest. The measurements were done with an appropriate sized cuff and an automatic, electronic device (Takeda Medical UA-751, Tokyo, Japan), which has been shown to be as reliable as Hawksley Random Zero sphygmomanometer [12]. Hypertension was defined according to the WHO criteria (blood pressure exceeding $160 / 95 \mathrm{~mm} \mathrm{Hg}$ and/or ongoing antihypertensive therapy). Mean blood pressure was calculated as diastolic blood pressure plus one third of the pulse pressure.

Body mass index $\left(\mathrm{kg} / \mathrm{m}^{2}\right)$, blood glucose (glucose GDH, Cobas Mira, Roche, Basle, Switzerland) and serum creatinine (by reaction rate kinetic principle eliminating pseudo-creatinines, interassay coefficient of variation was $2.5 \%$ ) [13] were measured.

Table 1. Clinical data of Type 1 (insulin-dependent) diabetic patients with or without nephropathy, their parents and of healthy control subjects. Mean \pm SD indicated except for blood glucose and urinary albumin which are given in median (quartiles)

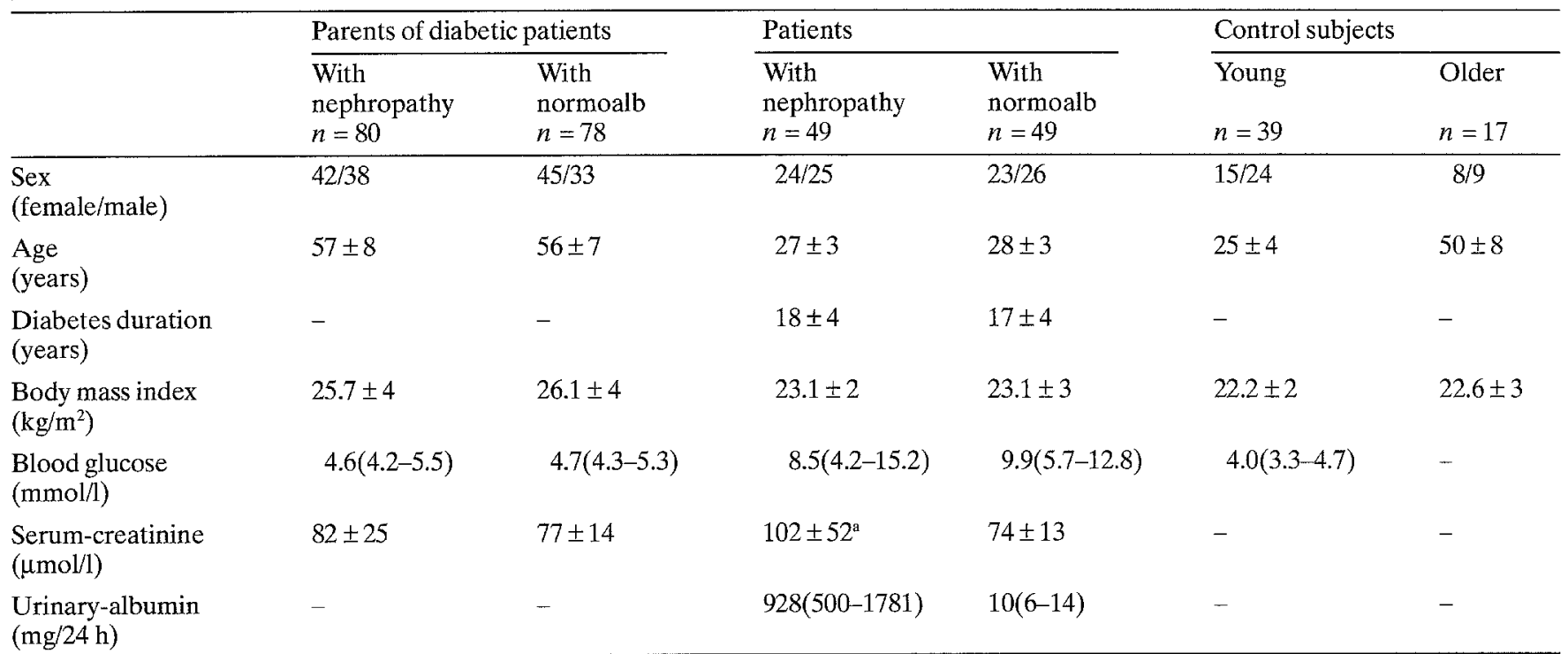

${ }^{a} p<0.01$ vs normoalbuminuric patients 


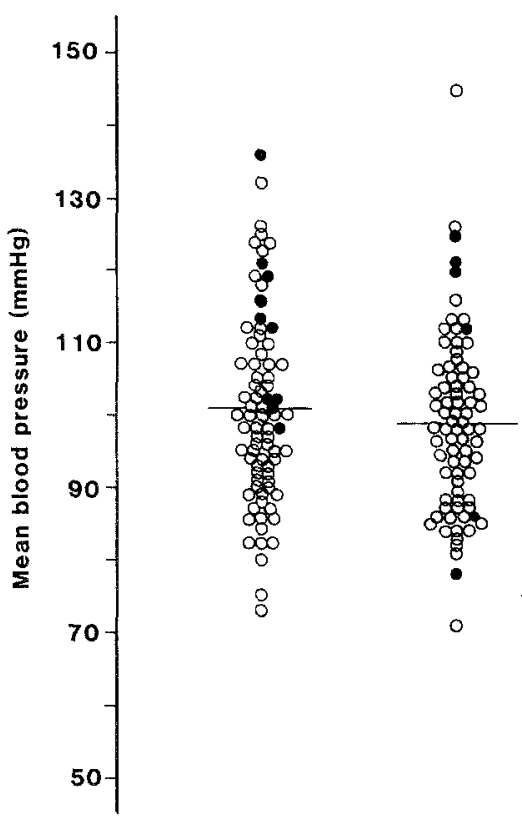

Fig. 2. Mean blood pressure in parents of Type 1 (insulin-dependent) diabetic patients with nephropathy (left column) and in parents of diabetic patients with normoalbuminuria (right column). Mean values are indicated by horizontal lines. $\bullet$ indicates that antihypertensive medication was instituted; $O$ indicates no antihypertensive medication

Urinary albumin excretion was measured in diabetic patients by an ELISA-technique (interassay coefficient of variation was $8.3 \%$ ) [14].

In all subjects the maximal $\mathrm{Na}^{+} / \mathrm{Li}^{+}$countertransport activity was measured as described previously from our laboratory $[15,16]$. Within $1 \mathrm{~h}$ after sampling, the erythrocytes were washed three times in an isotonic $\mathrm{KCl}$ medium containing $0.1 \mathrm{mmol} / \mathrm{l}$ of ouabain. The erythrocytes were stored in this medium at $4^{\circ} \mathrm{C}$ and analyses were performed at least within four days after sampling. Storage of the samples for even seven days did not affect the $\mathrm{Na}^{+} / \mathrm{Li}^{+}$countertransport. Erythrocytes were loaded with lithium in a bicarbonate medium. After having washed the cells back into $\mathrm{KCl}$ medium, mean corpuscular $\mathrm{Hb}$ concentration was determined and found normal, showing that cell volume and water content were normal. Furthermore, the intracellular sodium concentration was measured in all samples and found within the physiological range. We have demonstrated that transport parameters, changed in the presence of bicarbonate, return to normal after the cells have been washed back into chloride media [15]. Furthermore, we have found identical values for leak efflux in $\mathrm{KCl}$ medium and media used in other laboratories [16]. All chemicals employed were reagent grade. The interassay and the intraindividual coefficients of variation were 6.1 and $7.1 \%$, respectively. The laboratory was blinded with respect to the blood sample group.

Further information regarding clinical data were obtained from a review of medical records. In the control groups of healthy subjects height, weight, blood pressure and $\mathrm{Na}^{+} / \mathrm{Li}^{+}$countertransport were measured only. Blood glucose was measured only in the group of younger subjects.

\section{Statistical analysis}

Mean \pm SD or median (quartiles) are given when data are normally or not normally distributed. In order to test for differences between the six groups ANOVA was used. If significant differences were found Student's unpaired $t$-test (two-tailed) were used for comparison between the groups. $\mathrm{Na}^{+} / \mathrm{Li}^{+}$countertransport were not normally distributed and these data were analysed similarly with Kruskall-Wallis-test of variance and Mann-Whitney test. The prevalence of hypertension in the parental groups were compared with Chi-squared test. A $p$ value $<0.05$ was considered statistically significant. With alpha $=0.05$ and beta $=0.10,80$ parents in each group should be sufficient to detect a difference in diastolic blood pressure of $5 \mathrm{~mm} \mathrm{Hg}$ and a difference in $\mathrm{Na}^{+} / \mathrm{Li}^{+}$countertransport of $0.075 \mathrm{mmol} /(1 \mathrm{cells} \times \mathrm{h})$. Regression analyses between midparent averages and patient values of mean blood pressure and $\mathrm{Na}^{+} / \mathrm{Li}^{+}$ countertransport were carried out by the least squares method. Otherwise correlations were sought by using stepwise, multiple, linear regression analysis. Prior to regression analysis $\mathrm{Na}^{+} / \mathrm{Li}^{+}$ countertransport activity was $\log$ transformed.

\section{Results}

The clinical characteristics of the parents, the diabetic patients and the two control groups are given in Table 1.

The two groups of parents were similar with respect to age and sex distribution, body mass index, blood glucose and serum creatinine. In the patients the only significant

Table 2. Arterial blood pressure and $\mathrm{Na}^{+} / \mathrm{Li}^{+}$countertransport in parents of diabetic patients with or without nephropathy, their diabetic offspring and in healthy control subjects. Blood pressure indicated by mean $( \pm \mathrm{SD}), \mathrm{Na}^{+} / \mathrm{Li}^{+}$countertransport indicated by median (quartiles)

\begin{tabular}{|c|c|c|c|c|c|c|}
\hline & \multicolumn{2}{|c|}{ Parents of diabetic patients } & \multicolumn{2}{|l|}{ Patients } & \multicolumn{2}{|c|}{ Control subjects } \\
\hline & $\begin{array}{l}\text { With } \\
\text { nephropathy } \\
n=80\end{array}$ & $\begin{array}{l}\text { With } \\
\text { normoalb } \\
n=78\end{array}$ & $\begin{array}{l}\text { With } \\
\text { nephropathy } \\
n=49\end{array}$ & $\begin{array}{l}\text { With } \\
\text { normoalb } \\
n=49\end{array}$ & $\begin{array}{l}\text { Young } \\
n=39\end{array}$ & $\begin{array}{l}\text { Older } \\
n=17\end{array}$ \\
\hline $\begin{array}{l}\text { Systolic } \\
\text { blood pressure }(\mathrm{mm} \mathrm{Hg})\end{array}$ & $137 \pm 21$ & $133 \pm 20$ & $134 \pm 17^{a}$ & $125 \pm 10$ & $120 \pm 12$ & $122 \pm 11$ \\
\hline $\begin{array}{l}\text { Diastolic } \\
\text { blood pressure }(\mathrm{mm} \mathrm{Hg})\end{array}$ & $83 \pm 10$ & $81 \pm 10$ & $83 \pm 10^{\mathrm{a}}$ & $75 \pm 8$ & $73 \pm 9$ & $80 \pm 7$ \\
\hline $\begin{array}{l}\text { Prevalence of } \\
\text { hypertension (\%) }\end{array}$ & 25 & 19 & 80 & 2 & 0 & 0 \\
\hline $\begin{array}{l}\mathrm{Na}^{+} / \mathrm{Li}^{+} \text {countertransport } \\
(\mathrm{mmol} /(1 \text { cells } \times \mathrm{h})\end{array}$ & $\begin{array}{c}0.33 \\
(0.27 \\
-0.47) \\
\end{array}$ & $\begin{array}{c}0.32 \\
(0.27 \\
-0.41)\end{array}$ & $\begin{array}{c}0.48 \\
(0.35 \\
-0.57)^{c}\end{array}$ & $\begin{array}{c}0.41 \\
(0.34 \\
-0.50)^{\mathrm{b}}\end{array}$ & $\begin{array}{c}0.31 \\
(0.26 \\
-0.41)\end{array}$ & $\begin{array}{c}0.31 \\
(0.28 \\
-0.34)\end{array}$ \\
\hline
\end{tabular}

\footnotetext{
${ }^{\mathrm{a}} p<0.01$ vs normoalbuminuric patients; ${ }^{\mathrm{b}} p<0.002$ vs young control subjects; ${ }^{\mathrm{c}} p=0.06 \mathrm{vs}$ normoalbuminuric patients
} 


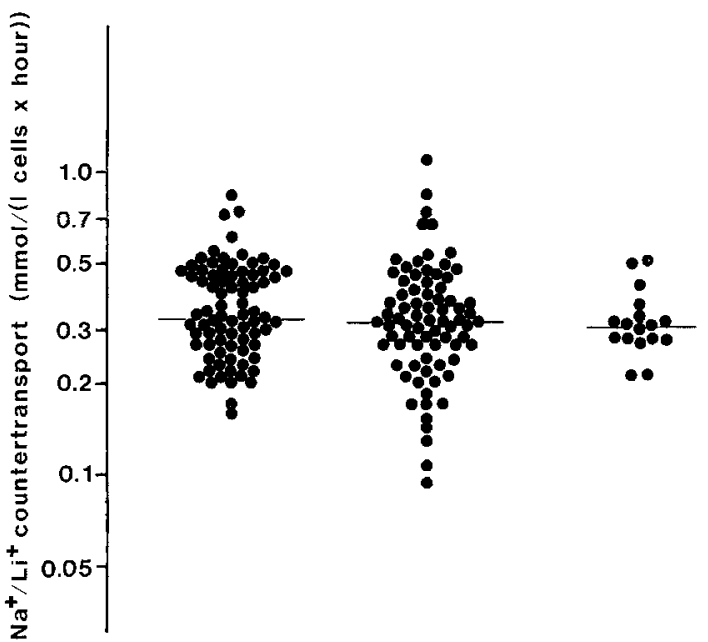

Fig.3. $\mathrm{Na}^{+} / \mathrm{Li}^{+}$countertransport in erythrocytes from parents of Type 1 (insulin-dependent) diabetic patients with nephropathy (left column), parents of diabetic patients with normoalbuminuria (middle) and in older non-diabetic control subjects (right column). Medians are indicated by horizontal lines
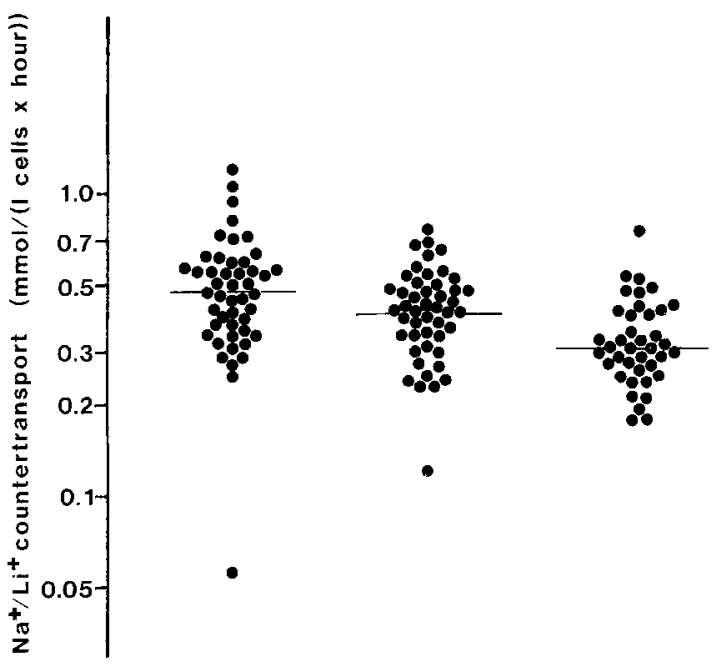

Fig. 4. $\mathrm{Na}^{+} / \mathrm{Li}^{+}$countertransport in erythrocytes from Type 1 (insulin-dependent) diabetic patients with (left column) or without nephropathy (middle) and in young non-diabetic control subjects (right column). Medians are indicated by horizontal lines

difference was the higher levels of serum creatinine in the nephropathy group compared to the normoalbuminuria group.

Systolic and diastolic blood pressures were nearly identical in the parents of diabetic patients with nephropathy as compared with the parents of normoalbuminuric diabetic patients (Table 2 and Fig.2). The prevalence of hypertension did not differ significantly between the groups (25 and 19\%) (Table 2). Neither did the prevalence of parents receiving antihypertensive medication (13 and $8 \%$ ) (Fig. 2).

Of the patients with nephropathy $80 \%$ were receiving antihypertensive treatment. Their blood pressure was, however, still significantly elevated when compared with the normoalbuminuric group $(p<0.01)$, (Table 2).
J.S. Jensen et al.: No predisposition to hypertension in diabetic nephropathy

The $\mathrm{Na}^{+} / \mathrm{Li}^{+}$countertransport in the two groups of parents and the healthy control subjects were not significantly different $(0.33,0.32$ and $0.31 \mathrm{mmol} /(1$ cells $\times \mathrm{h}))$ (Table 2 and Fig. 3).

$\mathrm{Na}^{+} / \mathrm{Li}^{+}$countertransport were elevated in both groups of patients with normoalbuminuria and with nephropathy as compared to non-diabetic control subjects $(0.42, \quad 0.48$ and $0.31 \mathrm{mmol} /(1 \mathrm{cells} \times \mathrm{h})$ respectively, $p<0.002$ ) (Table 2 and Fig. 4). The highest level was found in the patients with nephropathy, but the difference between the two diabetic groups just failed to reach statistical significance $(p=0.06)$. In patients with nephropathy a significant correlation between mean blood pressure and $\mathrm{Na}^{+} / \mathrm{Li}^{+}$countertransport was found $(r=0.51$, $p<0.001$ ).

Out of the families studied, in 49 families where both parents were examined and none of them received antihypertensive treatment, the midparent averages of mean blood pressure and $\mathrm{Na}^{+} / \mathrm{Li}^{+}$countertransport were calculated. Mean blood pressure and $\mathrm{Na}^{+} / \mathrm{Li}^{+}$countertransport in this subgroup of parents were similar to that found in the whole population investigated. A weak correlation was found between the $\mathrm{Na}^{+} / \mathrm{Li}^{+}$countertransport in the parents not receiving antihypertensive drugs and their diabetic offspring ( $n=49, r=0.30, p<0.02$ ). No significant correlation was found between mean blood pressure in the parents and their offspring $(r=0.03)$, or between $\mathrm{Na}^{+} / \mathrm{Li}^{+}$countertransport in the parents and mean blood pressure in the offsprings $(r=0.16)$. These correlations were not improved if parents treated with antihypertensive drugs were included.

\section{Discussion}

The major novel observations in our cross-sectional family study of Type 1 diabetic patients with or without nephropathy and their parents are the findings that arterial blood pressure, prevalence of arterial hypertension, and $\mathrm{Na}^{+} / \mathrm{Li}^{+}$countertransport are mainly identical in the two groups of parents. Furthermore, we have demonstrated that $\mathrm{Na}^{+} / \mathrm{Li}^{+}$countertransport is elevated in Type 1 diabetic patients with or without nephropathy, suggesting an effect of the diabetic state in itself. Finally, we have confirmed the original observation of an enhanced $\mathrm{Na}^{+} / \mathrm{Li}^{+}$ countertransport of Type 1 diabetic patients with nephropathy $[5,6]$.

The primary aim of this study was to evaluate whether a predisposition to essential hypertension was associated with an increased risk of developing clinical nephropathy in diabetic patients. If this was the case one would expect a higher prevalence of hypertension or higher arterial blood pressure levels in parents of diabetic patients with nephropathy compared with parents of normoalbuminuric diabetic patients. With a power of 0.9 our study excluded a difference of $5 \mathrm{~mm} \mathrm{Hg}$ in diastolic blood pressure between the two groups of parents. Hence, our study indicates that familial predisposition to essential hypertension is not a major marker for the risk of developing diabetic nephropathy. This observation is in contrast to the findings 
by Krolewski et al. [5] and Viberti et al. [7]. It should be noted that in the study by Krolewski et al. [5], the blood pressure of the parents was not measured. They obtained their data by a mailed questionnaire to the parents. Thus, only previously diagnosed hypertension was recorded, and hypertension was consequently defined by antihypertensive treatment and not by a specific blood pressure level. In the study by Krolewski et al. only the prevalence of at least one parent with hypertension was given. In the present study the prevalence of at least one parent with hypertension was $34 \%$ (offspring with normoalbuminuria) and $55 \%$ (offspring with nephropathy). Thus, the prevalence in our study is still lower than the prevalence found by Krolewski et al. (50\% and $77 \%$, respectively). Viberti et al. [7] compared the measured blood pressure in the parents of 17 proteinuric and 17 non-proteinuric Type 1 diabetic patients. Proteinuria was defined as urinary protein concentration $>0.15 \mathrm{~g} / \mathrm{l}$ in a single urine sample. They found a significantly higher blood pressure level in the parents of the proteinuric than of the non-proteinuric patients but only $42 \%$ of the possible parents were investigated. The $11 \mathrm{~mm} \mathrm{Hg}$ difference in their study would have been detected in our study if present.

The second aim of this study was to evaluate the potential role of increased $\mathrm{Na}^{+} / \mathrm{Li}^{+}$countertransport as a genetic marker for the risk of developing clinical nephropathy in Type 1 diabetic patients. If this was the case, higher levels of $\mathrm{Na}^{+} / \mathrm{Li}^{+}$countertransport would have been expected in parents of diabetic patients with nephropathy compared with parents of normoalbuminuric diabetic patients. We found, however, the $\mathrm{Na}^{+} / \mathrm{Li}^{+}$countertransport level to be nearly identical in the two groups of parents and of comparable level to the 17 healthy control subjects with similar age and sex distribution. The actual values of $\mathrm{Na}^{+} / \mathrm{Li}^{+}$countertransport in our control groups are comparable to the values found in other studies $[6,17,18]$. Furthermore, no correlation between midparent average of $\mathrm{Na}^{+} / \mathrm{Li}^{+}$ countertransport and mean blood pressure of the patients was demonstrated. Thus, our observation indicates that high $\mathrm{Na}^{+} / \mathrm{Li}^{+}$countertransport is not by itself a genetic marker for the risk of developing diabetic nephropathy. There is a large genetic contribution to the distribution of $\mathrm{Na}^{\div} / \mathrm{Li}^{+}$countertransport in nondiabetic subjects [19] and the present study also demonstrates a significant (though weak) correlation between the midparent average of $\mathrm{Na}^{+} / \mathrm{Li}^{+}$countertransport and $\mathrm{Na}^{+} / \mathrm{Li}^{+}$countertransport of the diabetic patients.

As demonstrated previously $[5,6,20] \mathrm{Na}^{+} / \mathrm{Li}^{+}$ countertransport is higher in patients with clinical nephropathy and/or hypertension than in normoalbuminuric patients. However, we found that both diabetic groups had significantly elevated $\mathrm{Na}^{+} / \mathrm{Li}^{+}$ countertransport when compared with their nondiabetic control counterparts. With the present crosssectional design of the study we cannot exclude, that increased $\mathrm{Na}^{+} / \mathrm{Li}^{+}$countertransport demonstrated in patients with diabetic nephropathy in combination with poor metabolic control has contributed to the devel- opment of nephropathy. As $\mathrm{Na}^{+} / \mathrm{Li}^{+}$countertransport was not increased in the parents, our observations do however, strongly suggest that the increased $\mathrm{Na}^{+} / \mathrm{Li}^{+}$ countertransport is associated with diabetes per se and not a genetic risk marker for the development of nephropathy.

It is still not known why $\mathrm{Na}^{+} / \mathrm{Li}^{+}$countertransport elevation seems to be associated with increased blood pressure. In fact, in our diabetic patients with nephropathy, who were characterized by a widespread range of both parameters, a significant correlation was found between $\mathrm{Na}^{+} / \mathrm{Li}^{+}$countertransport and mean blood pressure. The more pronounced difference in $\mathrm{Na}^{+} / \mathrm{Li}^{+}$ countertransport between diabetic patients with or without nephropathy found by Krolewski et al. [5] and Mangili et al. [6] could be due to the higher differences in blood pressure between their diabetic groups. This is also in accordance with the high association found between blood pressure and $\mathrm{Na}^{+} / \mathrm{Li}^{+}$countertransport in hypertensive Type 1 diabetic patients observed by Simplicini et al. [20]. However, no data regarding proteinuria was given in this study.

In conclusion, the present study indicates that predisposition to essential hypertension appears to play no significant role in the pathogenesis of clinical nephropathy in Type 1 diabetes. Neither blood pressure nor $\mathrm{Na}^{+} / \mathrm{Li}^{+}$countertransport - a possible genetic marker for essential hypertension - was significantly higher in parents of patients with diabetic nephropathy than in parents of diabetic patients with normoalbuminuria. Hence, increased $\mathrm{Na}^{+} / \mathrm{Li}^{+}$countertransport seems to be of no use as a genetic marker for the development of diabetic nephropathy in Type 1 diabetes.

Acknowledgement. This study was supported by Diabetesforeningen and Feldthusens Legat.

\section{References}

1. Borch-Johnsen K, Andersen PK, Deckert T (1985) The effect of proteinuria on relative mortality in Type 1 (insulin-dependent) diabetes mellitus. Diabetologia 28: 590-596

2. Andersen AR, Sandahl Christiansen J, Andersen JK, Kreiner S, Deckert T (1983) Diabetic nephropathy in Type 1 (insulin-dependent) diabetes: an epidemiological study. Diabetologia 25: 496-501

3. Wiseman M, Viberti G, Machintosh D, Jarret RJ, Keen H (1984) Glycaemia, arterial pressure and microalbuminuria in Type 1 (insulin-dependent) diabetes mellitus. Diabetologia 26: 401-405

4. Mathiesen ER, Oxenbøll B, Johansen K, Svendsen PA, Deckert $\mathrm{T}$ (1984) Incipient nephropathy in Type 1 (insulin-dependent) diabetes. Diabetologia 26: 406-410

5. Krolewski AS, Canessa M, Warram JH, Laffel LM, Christlieb AR, Knowler WC, Rand LI (1988) Predisposition to hypertension and susceptibility to renal disease in insulin-dependent diabetes mellitus. N Engl J Med 318: 140-145

6. Mangili R, Bending JJ, Scot G, Li LK, Gupta A, Viberti G (1988) Increased sodium-lithium countertransport activity in red cells of patients with insulin-dependent diabetes and nephropathy. NEngl J Med 318: 146-150

7. Viberti GC, Keen H, Wiseman MJ (1987) Raised arterial pressure in parents of proteinuric insulin dependent diabetes. $\mathrm{Br}$ Med J 295: 515-517 
8. Canessa M, Adragna N, Solomon HS, Connoly TM, Tosteson DC (1980) Increased sodium-lithium countertransport in red cells of patients with essential hypertension. N Engl J Med 302: $772-776$

9. Cooper R, Le Grady D, Nanas S, Trevisan M, Mansour M, Histand P, Ostrow D, Stamler J (1983) Increased sodium lithium countertransport in college students with elevated blood pressure. JAMA 249: 1030-1034

10. Woods JW, Falck RJ, Pittman AW, Klemmer PJ, Watson BS, Namboodire K (1982) Increased sodium-lithium countertransport in normotensive sons of hypertensive parents. N Engl J Med 306: 593-595

11. Parving H-H, Andersen AR, Smidt UM, Hommel E, Mathiesen ER, Svendsen PA (1987) Effect of antihypertensive treatment on kidney function in diabetic nephropathy. Br Med J 285: 685-688

12. Carsten JE, Køber L, Hansen A-D, Sinding A, Andersen P (1988) Electronic measurement of blood pressure. Technical and clinical assesment of Medical UA 751. Ugeskr Laeger 150: 1280 1282

13. Larsen K (1972) Serum-creatinine. Clin Chim Acta 41: 209-217

14. Feldt-Rasmussen B, Dinesen B, Deckert M (1985) Enzyme immunoassay: an improved determination of urinary albumin in diabetics with incipient nephropathy. Scan J Clin Lab Invest 45: 539-544

15. Funder J, Tosteson D, Wieth JO (1978) Effects of bicarbonate on lithium transport in human red cells. J Gen Physiol 71: 720-746

16. Ibsen KK, Jensen HÆ, Wieth JO, Funder J (1982) Essential hypertension: sodium-lithium countertransport in erythrocytes from patients and from children having one hypertensive parent. Hypertension 4: 5: 703-709

17. Turner ST, Johnson M, Boerwinkle E, Richelson E, Taswell HF, Sing CF (1985) Sodium-lithium countertransport and blood pressure in healthy blood donors. Hypertension 7: 955-962

18. Adragna NC, Chang JL, Morey MC, Williams RC (1985) Effect of exersise on cation transport in human red cells. Hypertension 7:132-139

19. Boerwinkel E, Turner T, Weinshilboum R, Johnson M, Richelson E, Sing CF (1986) Analysis of the distribution of erythrocyte sodium lithium countertransport in a sample representative of the general population. Genetic Epidemiology 3:365-378

20. Simplicini A, Mozzato M-G, Sama'B, Nosadini R, Fioretto P, Trevisan R, Pessina AC, Crepaldi G, Dal Palu' C (1989) Na/H and $\mathrm{Li} / \mathrm{Na}$ exchange in red blood cells of normotensive and hypertensive patients with insulin dependent diabetes mellitus (IDDM). Am J Hypertens 2: 174-177

Received: 14 December 1989

and in revised form: 30 April 1990

Dr. K. Nørgaard

Steno Memorial Hospital

DK-2820 Gentofte

Denmark 